\title{
Klasifikasi Multi Class Pada Analisis Sentimen Opini Pengguna Aplikasi Mobile Untuk Evaluasi Faktor Usability
}

\author{
Septiyawan Rosetya Wardhana ${ }^{1}$, Diana Purwitasari ${ }^{2}$ \\ ${ }^{1}$ Teknik Informatika, Fakultas Teknologi Informasi, Institut Teknologi Adhi Tama Surabaya \\ ${ }^{2}$ Informatika, Fakultas Teknologi Informasi dan Komunikasi, Institut Teknologi Sepuluh Nopember \\ Email: 'rossywardhana@itats.ac.id, ${ }^{2}$ diana@if.its.ac.id
}

\begin{abstract}
In software development and evaluation process, usability factor is the most important aspect. Usability factor evaluation can be done by analyzing sentiment orientation in user review based on usability factor. But, every review also has its sentiment level which reflect the high and low sentiment orientation. So that, it will be more effective if sentiment level is also considered in evaluation process. Moreover, user review can have more than 1 usability factors. It is because every review document can be contain more than 1 sentences where every sentence can have different usability factor. Different with another software, mobile application has context and limits of its own. So, usability model which is used also different with another software. PACMAD model is a usability model which is customized with context and limitation from mobile apllication. Therefore, in this research is proposed an usability factor evaluation method using multi class classification in sentiment analysis which considers mobile application user review sentiment level based on PACMAD usability model. User review data is classified using multi class classification based on naive bayes method. Than, that review will be analyzed its sentiment orientation and level using SentiWordNet Interpretation method. Based on test result, it is gained $74.7 \%$ accuration value, precision $43.2 \%$, recall $29.5 \%$ and $f$-measure $34.5 \%$.
\end{abstract}

Abstrak. Dalam proses pengembangan maupun pengujian perangkat lunak, faktor usability merupakan aspek yang paling penting. Evaluasi faktor usability tersebut dapat dilakukan dengan menganalisa orientasi sentimen pada opini pengguna berdasarkan faktor usability. Namun, setiap opini juga memiliki tingkat sentimen yang mencerminkan tinggi rendahnya orientasi sentimen, sehingga akan lebih efektif apabila tingkat sentimen juga dipertimbangkan dalam proses evaluasi. Selain itu, opini pengguna juga dapat memiliki lebih dari 1 faktor usability. Hal tersebut dikarenakan setiap dokumen opini dapat terdiri lebih dari 1 kalimat dimana setiap kalimat bisa memiliki faktor usability yang berbeda. Berbeda dengan perangkat lunak lainnya, aplikasi mobile memiliki batasan dan konteks tersendiri. Sehingga model usability yang digunakan juga berbeda dengan perangkat lunak lainnya. Model PACMAD merupakan model usability yang disesuaikan dengan batasan dan konteks dari aplikasi mobile. Oleh karena itu dalam penelitian ini diusulkan suatu metode evaluasi faktor usability dengan menggunakan klasifikasi multi class pada analisis sentimen dengan mempertimbangkan tingkat sentimen opini pengguna aplikasi mobile berdasarkan model usability PACMAD. Data opini pengguna dikaslifikasian dengan model klasifikasi multi class dengan metode naive bayes, kemudian dianalisis orientasi dan tingkat sentimennya dengan menggunakan metode SentiWordNet Interpretation. Berdasarkan hasil ujicoba diperoleh nilai akurasi sebesar $74,7 \%$, precision $43,2 \%$, recall $29,5 \%$ dan f-measure $34,5 \%$.

Kata Kunci: Analisis Sentimen, Klasifikasi Multi-Class, Model PACMAD, Faktor Usability

\section{Pendahuluan}

Aplikasi mobile merupakan salah satu jenis perangkat lunak yang banyak digunakan oleh pengguna teknologi informasi saat ini. Aplikasi mobile atau apps merupakan jenis perangkat lunak yang dijalankan pada perangkat mobile seperti smartphone, tablet, smartwatch maupun perangkat mobile lainnya (Patel \& Dalal, 2013). Dalam proses pengujian maupun evaluasi perangkat lunak, beberapa faktor perlu dipertimbangkan dalam proses tersebut. Salah satu faktor yang paling penting dalam proses pengujian maupun evaluasi tersebut adalah faktor kebergunaan atau usability (Baharuddin, Singh, \& Razali, 2013). Faktor usability merupakan salah satu atribut kualitas perangkat lunak yang 
merefleksikan bagaimana pengalaman pengguna dalam menggunakan perangkat lunak. Pengalaman pengguna tersebut meliputi tingkat kemudahan perangkat lunak serta kenyamanan pengguna dalam menggunakan perangkat lunak tersebut (Flood, Harrison, Iacob, \& Duce, 2012). Bagaimanapun juga dalam proses evaluasi maupun pengujian perangkat lunak pasti melibatkan pengguna sebagai acuan pengukurannya. Salah satu bentuk perwujudan pengalaman pengguna dalam menggunakan aplikasi mobile adalah opini pengguna (Kaur \& Gumber, 2014). Opini pengguna merupakan bagian dari teks yang mengandung nilai informasi tentang pengalaman pengguna dalam menggunakan perangkat lunak (Atoum \& Otoom, 2016). Opini pengguna mengandung suatu komentar maupun persepsi pengguna yang dapat dijadikan salah satu aspek untuk mengukur kualitas suatu perangkat lunak.

Berkaitan dengan evaluasi faktor usability, El Hales dalam penelitiannya pernah menggunakan model usability pada ISO 9241-1 yang meliputi effectiveness, efficiency dan satisfaction sebagai faktor untuk mengevaluasi usability perangkat lunak. Metode yang digunakan dalam penelitian tersebut adalah opinion mining atau penambangan opini (El-Halees, 2014). Kemudian dengan menentukan orientasi sentimen berdasarkan metode opinion mining, opini pengguna akan diklasifikasikan ke dalam orientasi positif, negatif atau netral (Sharma \& Chitre, 2014). Hasil dari penelitian tersebut adalah ratarata jumlah opini positif dan negatif yang telah dikelompokkan berdasarkan faktor usability. Proses penentuan sentimen dalam penelitian tersebut belum mempertimbangkan tingkat sentimen serta nilai orientasi kata pada kalimat terhadap opini pengguna. Selain itu, proses klasifikasi yang digunakan juga belum mempertimbangkan kemungkinan faktor multi class pada opini pengguna (Wardhana, Purwitasari, \& Rochimah, n.d.). Dimana dokumen opini pengguna yang terdiri lebih dari 1 kalimat dapat memiliki class atau faktor usability yang berbeda pada setiap kalimatnya. Zhikov dkk dalam penelitiannya juga mengusulkan klasifikasi multi class atau multi label pada dokumen teks dengan menggunakan beberapa metode klasifikasi (Zhikov, Tolo, Ivanov, \& Georgiev, n.d.).

Berbeda dengan jenis perangkat lunak lainnya, aplikasi mobile memiliki batasan-batasan dan konteks tersendiri yang membuatnya memiliki model usability yang berbeda dengan aplikasi maupun perangkat lunak lain (Harrison, Flood, \& Duce, 2013b). Harrison dkk dalam penelitiannya mengusulkan model usability baru yang disesuaikan dengan batasan dan konteks yang dimiliki aplikasi mobile. Model usability tersebut adalah PACMAD yang dapat digunakan sebagai guideline dalam mendesain maupun mengevaluasi aplikasi mobile yang terdiri dari effectiveness, efficiency, satisfaction, learnability, memorability, errors dan cognitive load (Harrison, Flood, \& Duce, 2013a). Berdasarkan permasalahan-permasalahan tersebut maka dalam penelitian ini diusulkan suatu metode evaluasi faktor usability dengan menggunakan klasifikasi multi class pada analisis sentimen dengan mempertimbangkan tingkat sentimen opini pengguna aplikasi mobile berdasarkan model usability PACMAD. Penggunaan metode klasifikasi multi class, model PACMAD dan penambahan tingkat sentimen dalam evaluasi faktor usability aplikasi mobile diharapkan dapat menghasilkan nilai evaluasi usability yang lebih akurat dan sesuai dengan konteks dan batasan pada aplikasi mobile.

\section{Kajian Pustaka}

Usability merupakan faktor yang cukup signifikan dalam proses pengembangan maupun pengujian perangkat lunak. Menurut Alaa dkk, usability merupakan suatu ukuran atau tingkat dimana suatu produk dapat digunakan oleh pengguna untuk mencapai tujuan pembuatan produk yang sebenarnya dengan efektif, efisien dan penuh kepuasan dari segi konteks penggunaan (El-Halees, 2014). Konsep usability yang disebutkan sebelumnya merupakan konsep usability pada aplikasi desktop. Sehingga semua faktor-faktor yang diajukan pada usability tersebut didasarkan pada kebutuhan maupun pengembangan aplikasi desktop (Zaid, Jamaludin, \& Wafaa, 2012).

Berbeda dengan aplikasi desktop pada umumnya, aplikasi mobile memiliki arsitektur dan kebutuhan yang berbeda (Lapin, 2014). Hal tersebut dikarenakan aplikasi mobile memiliki batasanbatasan khusus yang tidak bisa disamakan dengan aplikasi desktop. Sehingga model usability pada aplikasi $m$ mempertobile tidak bisa disamakan dengan model usability pada aplikasi desktop. Dalam penelitiannya, Harrison dkk mengusulkan model usability PACMAD (People At the Centre of Mobile Application Development) dimana struktur dari model usability tersebut mempertimbangkan isu-isu 
dan batasan-batasan yang dimiliki oleh aplikasi mobile (Harrison et al., 2013b). Model usability tersebut merupakan penggabungan antara model usability ISO dan Nielsen serta ditambahkan faktor cogitive load yang dimiliki oleh aplikasi mobile. Tabel 1 dibawah ini menunjukkan faktor-faktor yang ada pada model usability PACMAD.

Tabel 1. Model Usability PACMAD

\begin{tabular}{|l|l|}
\hline Faktor Usability & \multicolumn{1}{|c|}{ Penjelasan } \\
\hline Effectiveness & $\begin{array}{l}\text { Sumber daya yang dikeluarkan sehubungan dengan tujuan dan } \\
\text { konteks spesifik perangkat lunak. }\end{array}$ \\
\hline Efficiency & $\begin{array}{l}\text { Sumber daya yang dikeluarkan sehubungan dengan akurasi dan } \\
\text { kelengkapan dalam mencapai tujuan pengguna. }\end{array}$ \\
\hline Satisfaction & $\begin{array}{l}\text { Tingkat kesenangan dan kepuasan yang diusahakan untuk pengguna } \\
\text { melalui penggunaan aplikasi. }\end{array}$ \\
\hline Error & $\begin{array}{l}\text { Kemudahan pengguna dalam memperoleh keahlian dalam } \\
\text { menggunakan aplikasi mobile }\end{array}$ \\
\hline Learnability & $\begin{array}{l}\text { Kemampuan pengguna untuk menguasai penggunaan aplikasi } \\
\text { secara efektif }\end{array}$ \\
\hline Memorability & Kesalahan yang dibuat oleh sistem \\
\hline Cognitive Load & $\begin{array}{l}\text { Beban kognitif yang diterima pengguna saat menggunakan aplikasi } \\
\text { mobile }\end{array}$ \\
\hline
\end{tabular}

\subsection{Data}

Data yang digunakan dalam penelitian ini adalah data opini pengguna aplikasi mobile berbahasa Inggris. Data tersebut diperoleh dari Google Playstore dengan menggunakan metode crawling. Google Playstore dipilih karena merupakan salah satu pusat aplikasi mobile android terbesar yang ada saat ini. Data berupa dokumen opini pengguna aplikasi mobile diambil melalui website Google Playstore dengan metode crawling dengan memanfaatkan HTML Parser (Padioleau, 2010). Pada proses crawling diambil dokumen opini pengguna yang meliputi nama reviewer, opini pengguna, tanggal dan rating. Jumlah aplikasi mobile yang digunakan dalam penelitian ini adalah 5 aplikasi mobile yang meliputi Whatsapp Messenger, Google Street View, Instagram, Waze dan Line. Aplikasi-aplikasi tersebut dipilih berdasarkan fitur dan tingkat kompleksitas aplikasi yang mempengaruhi faktor usability. Jumlah data opini pengguna yang digunakan dalam penelitian ini adalah 1500 dokumen opini. Dimana jumlah tersebut akan dibagi kembali ke dalam 2 bagian yaitu data training dan data testing.

Kemudian data opini pengguna tersebut akan diberi label faktor usability oleh para ahli. Data akan dianggap valid dan diterima sebagai data training apabila keseluruhan ahli yang memberi label tersebut memiliki kesepakatan yang sama mengenai faktor usability yang dilabelkan pada data tersebut. Jumlah data training yang digunakan dalam penelitian ini adalah 1000 data training, dimana masing-masing aplikasi mobile akan memiliki 200 data training. Sedangkan jumlah data testing yang digunakan adalah 500 data testing, dimana masing-masing aplikasi mobile terdiri dari 100 data testing. Data yang sudah diberi label oleh para ahli tersebut akan menjadi groundtruth atau data kebenaran untuk proses klasifikasi faktor usability.

Sedangkan untuk data kebenaran analisis sentimen pada penelitian ini akan menggunakan rating. Gambar 1 dibawah ini menunjukkan tahapan metode crawling opini pengguna yang digunakan dalam penelitian ini. Sedangkan Gambar 2 dibawah ini menunjukkan contoh data opini pengguna aplikasi mobile yang digunakan dalam penelitian ini. 


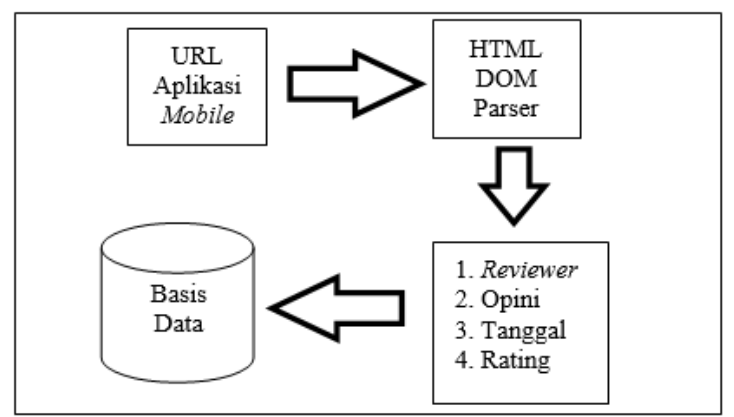

Gambar 1. Tahapan metode crawling data opini pengguna

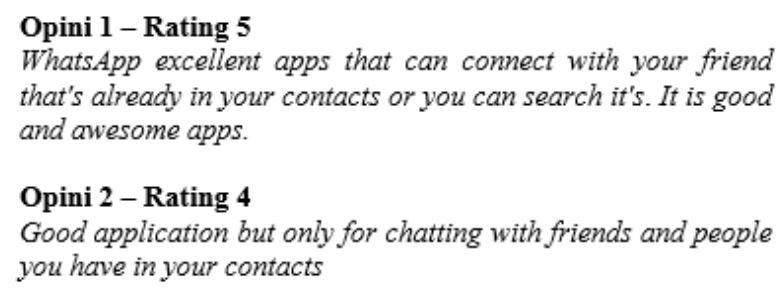

Gambar 2. Contoh data opini pengguna aplikasi mobile

\section{Metode Penelitian}

Pada penelitian mengenai analisis sentimen untuk evaluasi faktor usability ini, data yang digunakan sebagai data masukan adalah data opini pengguna aplikasi mobile. Kemudian data masukan tersebut akan melalui beberapa proses yang meliputi preprocessing, klasifikasi multi class pada faktor usability dan perhitungan sentimen. Sedangkan hasil keluaran setelah melalui proses tersebut adalah faktor usability dari data opini yang bersangkutan, orientasi sentimen (positif, negatif dan netral), serta tingkat sentimen yang memiliki rentang nilai antara 0 sampai dengan 1 . Kemudian hasil keluaran tersebut akan dianalisa kembali untuk mengetahui hasil evaluasi dari masing-masing faktor usability pada setiap aplikasi mobile yang diujikan berdasarkan model usability PACMAD. Terdapat beberapa tahapan yang harus dilalui untuk memperoleh hasil evaluasi faktor usability pada suatu aplikasi mobile. Salah satu tahapan awal yang cukup penting dalam penelitian ini adalah tahap preprocessing. Gambar 3 dibawah ini menjelaskan tentang alur kerja metode yang diusulkan dalam penelitian ini.

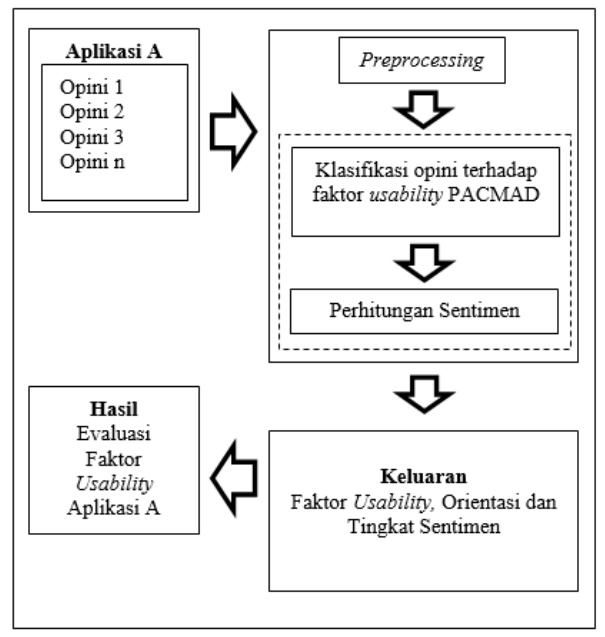

Gambar 3. Alur kerja metode yang diusulkan

\subsection{Preprocessing}

Preprocessing merupakan tahapan awal yang harus dilakukan dalam penelitian ini. Dalam tahapan ini akan dilakukan persiapan data yang nantinya digunakan untuk proses klasifikasi multi class 
terhadap faktor usability berdasarkan model PACMAD. Gambar 4 dibawah ini menunjukkan tahapan dalam preprocessing.

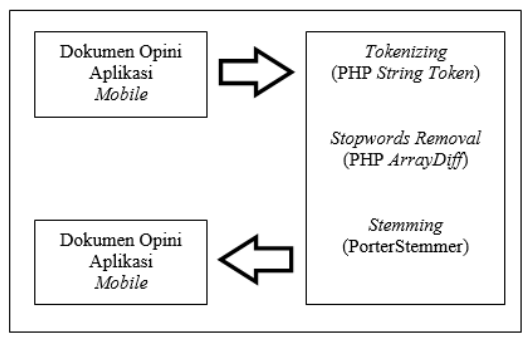

Gambar 4. Tahapan Preprocessing

Berdasarkan Gambar 4 dijelaskan bahwa pada tahap preprocessing ini terdapat beberapa bagian proses yang antara lain adalah tokenizing, stopwords removal, dan stemming. Tokenizing merupakan proses memecah dokumen maupun kalimat menjadi kata atau term (Vidyapith, 2014). Dalam proses ini, spasi dan tanda baca lainnya akan dihilangkan sehingga menghasilkan output berupa daftar kata atau term dalam bentuk list atau array. Proses tokenizing dalam penelitian menggunakan fungsi PHP String Token atau strtok() yang telah disediakan oleh library PHP.

Stopwords removal dilakukan untuk menghilangkan kata-kata yang sering muncul dan tidak diperlukan seperti and, or, in, at dan stopword lainnya (Lo, He, \& Ounis, n.d.). Untuk proses menghilangkan stopword pada penelitian ini menggunakan fungsi PHP Array Different atau arraydiff() yang telah disediakan oleh library array pada PHP. Sedangkan dalam proses stemming, kata atau term yang dihasilkan dari proses stopwords removal akan diubah menjadi root kata atau kata dasar.Untuk proses stemming sendiri bisa memanfaatkan library yaitu dari PorterStemmer (Ben \& Karaa, 2013).

\subsection{Klasifikasi Multi-Class}

Klasifikasi multi class yang dilakukan dalam penelitian ini bertujuan untuk mengkategorikan suatu opini pengguna aplikasi mobile ke dalam beberapa faktor usability. Hal tersebut dikarenakan pada dokumen opini pengguna terdiri dari beberapa kalimat dimana pada beberapa kasus dapat memiliki nilai faktor usability yang berbeda pada setiap kalimatnya. Gambar 5 dibawah ini menunjukkan beberapa contoh dokumen opini pengguna yang memiliki beberapa faktor usability yang berbeda.

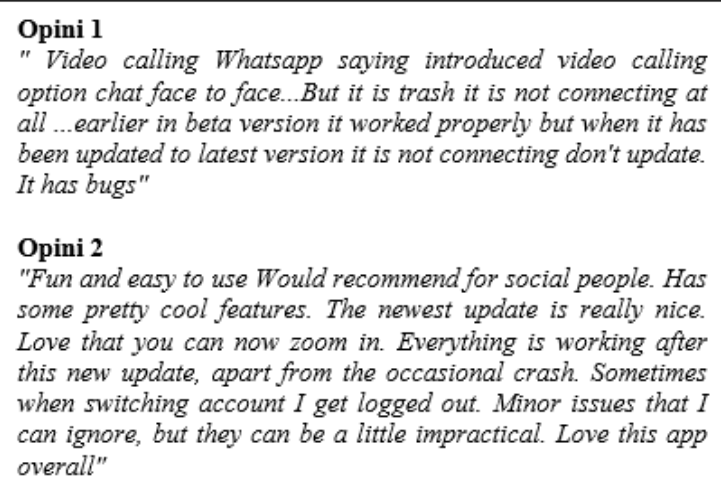

Gambar 5. Contoh Opini Pengguna Multi-Class

Berdasarkan opini 1 pada Gambar 5 diatas, kalimat "Video calling Whatsapp saying introduced video calling option chat face to face" merupakan kalimat pernyataan yang mencerminkan faktor effectiveness dan pada kalimat selanjutnya sampai akhir lebih mencerminkan kearah faktor usability error. Sedangkan pada opini 2, kalimat 1 sampai kalimat 4 yaitu "Fun and easy to use. Would recommend for social people. Has some pretty cool features. The newest update is really nice. Love that you can now zoom in." lebih mengarah ke faktor satisfaction dan learnability. Pada kalimat berikutnya sampir akhir lebih mengarah ke faktor error. Berdasarkan permasalahan diatas maka 
digunakanlah klasifikasi multi class sebagai salah satu pengembangan evaluasi faktor usability aplikasi mobile.

Proses klasifikasi multi class dalam penelitian ini menggunakan metode naive bayes. Metode ini menghitung probabilitas kata terhadap class atau faktor usability (Frank \& Bouckaert, n.d.). Kemudian setiap kalimat pada opini pengguna akan dihitung nilai probabilitasnya terhadap faktor usability dengan metode naive bayes. Faktor usability dari setiap kalimat inilah yang nantinya dijadikan acuan dalam menentukan faktor usability multi class dari suatu opini pengguna. Untuk tahapan klasifikasi dapat dilihat pada Gambar 6 dibawah ini.

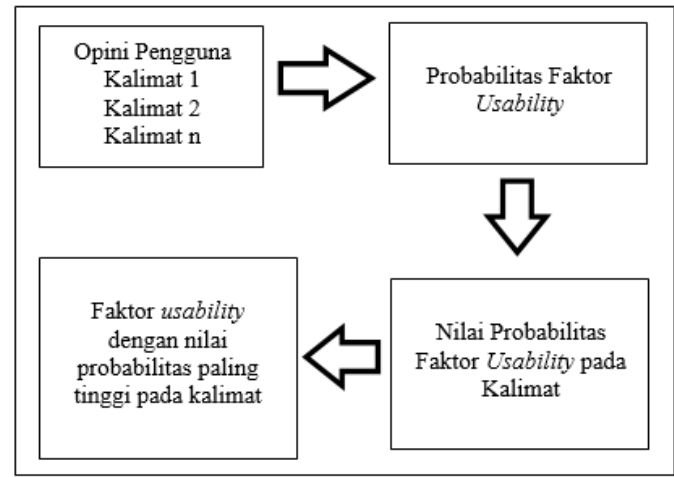

Gambar 6. Tahapan Klasifikasi Multi-Class

Berdasarkan Gambar 6 maka dapat disimpulkan bahwa pada proses klasifikasi multi class, opini pengguna yang berupa dokumen akan dipecah berdasarkan kalimat. Kemudian akan dihitung nilai probabilitas pada setiap faktor usability yang dimodelkan berdasarkan data training dengan metode naive bayes. Untuk formula perhitungan nilai probabilitas faktor usability berdasarkan metode naive bayes dapat dilihat pada Persamaan 1.

$$
P\left(y_{k} \mid x_{1}, x_{2}, \ldots . x_{a}\right)
$$

Berdasarkan Persamaan 1, probabilitas setiap faktor usability dihitung dengan membandingkan jumlah faktor usability yang bersangkutan dengan jumlah keseluruhan faktor usability yang ada pada data training. Selanjutnya setiap kalimat akan dihitung nilai probabilitasnya pada setiap faktor usability. Dimana nilai probabilitas faktor usability yang paling tinggilah yang akan menjadi class pada kalimat tersebut. Formula perhitungan probabilitas faktor usability pada kalimat dapat dilihat pada Persamaan 2 berikut.

$$
\boldsymbol{P}\left(y_{k} \mid x_{a}\right)=\frac{\boldsymbol{P}\left(y_{k}\right) \boldsymbol{P}\left(x_{a} \mid y_{k}\right)}{\boldsymbol{P}\left(x_{a}\right)}
$$

Berdasarkan Persamaan 2, proses perhitungan naive bayes pada kalimat dilakukan dengan menghitung probabilitas kemunculan setiap kata $\mathrm{x}_{\mathrm{a}}$ pada faktor usability $\mathrm{y}_{\mathrm{k}}, \mathrm{P}(\mathrm{xa} \mid \mathrm{yk})$ dikalikan dengan probabilitas faktor usability $\mathrm{P}(\mathrm{yk})$. Dari hasil tersebut kemudian dilakukan pembagian dengan kemunculan terhadap kemunculan dokumen $\mathrm{P}(\mathrm{xa})$. Kemudian, setiap kalimat akan memiliki class atau faktor usability dengan probabilitas tertinggi. Faktor usability dengan probabilitas tertinggilah yang akan menjadi class pada kalimat tersebut. Faktor usability dari setiap kalimat pada dokumen kemudian dikumpulkan dan akan menjadi label atau class dari dokumen tersebut. Class atau faktor usability dengan jumlah paling banyak pada suatu dokumen akan menjadi class teratas dalam klasifikasi multi class.

\subsection{Perhitungan Sentimen}

Perhitungan sentimen merupakan tahapan menghitung tingkat sentimen dan menentukan apakah suatu dokumen opini pengguna bersifat positif, negatif, atau netral. Tahapan perhitungan sentimen pada penelitian ini dapat dilihat pada Gambar 7 dibawah ini. 


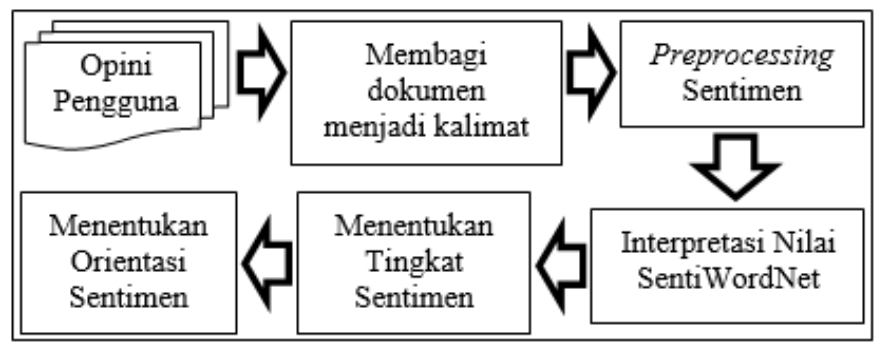

Gambar 7. Tahapan perhitungan sentimen

Gambar 7 diatas menjelaskan bahwa tahapan yang dilakukan untuk perhitungan sentimen opini pengguna antara lain adalah membagi dokumen berdasarkan kalimat, preprocessing untuk sentimen, menginterpretasi nilai SentiWordNet, menentukan tingkat sentimen dan menentukan orientasi sentimen. Pada tahap pembagian dokumen berdasarkan kalimat, opini pengguna yang berupa dokumen akan dibagi menjadi kumpulan kalimat. Selanjutnya, setiap kalimat pada dokumen opini akan dimasukkan dalam preprocessing untuk sentimen meliputi tokenizing, stopwords removal dan POS Tagging yang telah dijelaskan pada proses sebelumnya. Setelah melalui preprocessing, opini pengguna akan diolah kembali pada proses interpretasi SentiWordNet. Dalam interpretasi SentiWordNet, opini pengguna akan dicocokkan dengan SentiWordNet untuk mencari nilai sentimen yang sesuai dengan kata yang dicocokkan (Hamouda \& Rohaim, 2011). Tujuan dari tahapan ini adalah untuk mencari nilai sentimen yang mewakili setiap kata yang ada pada opini pengguna sesuai dengan arti dan tag kata tersebut.

Interpretasi SentiWordNet dilakukan dengan menghitung rata-rata nilai positif dan negatif dari setiap kata dalam opini pengguna yang diujikan berdasarkan pengelompokkan kategori kata atau tag yang meliputi kata benda, kata sifat, kata kerja maupun keterangan pada SentiWordNet (Ohana \& Tierney, 2009). Jadi hasil dari tahapan ini adalah interpretasi nilai positif dan negatif dari kata berdasarkan kelompok tag nya. Sebagai contoh, kata "good" dalam SentiWordNet memiliki beberapa sense yang berbeda meliputi 4 sense dalam kata benda, 21 sense dalam kata sifat dan 2 sense dalam keterangan. Sehingga untuk perhitungan interpretasi SentiWordNetnya dilakukan dengan menghitung rata-rata nilai positif dan negatif dari kata "good" pada setiap kategori kata. Hasil dari perhitungan tersebut dapat dilihat pada Tabel 2.

Tabel 2. Model Usability PACMAD

\begin{tabular}{|l|l|l|c|c|}
\hline No & Kata & Tag & Rata-rata Positif & Rata-rata Negatif \\
\hline 1 & Good & Noun & 0.531 & 0 \\
\hline 2 & Good & Adjective & 0.5 & 0 \\
\hline 3 & Good & Adverb & 0.188 & 0 \\
\hline
\end{tabular}

Tahap selanjutnya adalah menentukan tingkat dan orientasi sentimen. Pada tahap ini akan dihitung nilai polaritas dari opini pengguna yang nantinya digunakan sebagai acuan untuk menentukan tingkat dan orientasi sentimen dari opini pengguna tersebut. Tujuan tahap ini adalah menghitung tingkat sentimen dan menentukan apakah opini pengguna bersifat positif, negatif atau netral. Metode yang digunakan pada tahap ini adalah metode rata-rata kalimat dan rata-rata opini. Dimana metode ini mempertimbangkan nilai atau arti kata pada suatu kalimat serta nilai positif dan negatif dari kata yang memiliki pengaruh terhadap tingkat sentimen kata. Opini pengguna yang sudah dibagi menjadi kalimat dan melalui tahap preprocessing akan dihitung nilai interpretasi positif dan negatifnya menggunakan metode SentiWordNet interpretation yang telah dijelaskan sebelumnya. Setelah itu, rata-rata nilai positif dan nilai negatif akan dihitung berdasarkan jumlah interpretasi kata positif dan negatif yang ada pada kalimat tersebut. Kemudian, setelah semua rata-rata nilai positif dan negatif pada setiap kalimat diperoleh maka akan dihitung rata-rata nilai positif dan negatif pada opini. Ratarata nilai positif dan negatif pada opini inilah yang dijadikan sebagai tingkat sentimen, dimana tingkat sentimen yang paling tinggi dalam suatu opini akan dijadikan sebagai orientasi sentimen. Apabila tingkat sentimen positif lebih tinggi daripada tingkat sentimen negatif maka opini akan memiliki orientasi sentimen positif, dan apabila tingkat sentimen negatif lebih tinggi maka opini akan 
berorientasi negatif. Namun apabila tingkat sentimen antara positif dan negatif memiliki nilai yang sama maka opini akan dianggap objektif atau netral.

\section{Hasil dan Pembahasan}

Pada bab hasil dan pembahasan ini, hasil dari ujicoba penelitian ini akan dibandingkan dengan penelitian sebelumnya yang menggunakan klasifikasi single class. Berdasarkan hasil ujicoba klasifikasi single class yang dilakukan dengan menggunakan 500 data testing dan 1000 data training pada 5 aplikasi mobile yang meliputi Whatsapp Messenger (WA), Google Street View (GSV), Instagram (IG), Waze dan Line, maka diperoleh hasil evaluasi orientasi dan tingkat sentimen yang dapat dilihat pada Gambar 8 dan Gambar 9 dibawah ini.

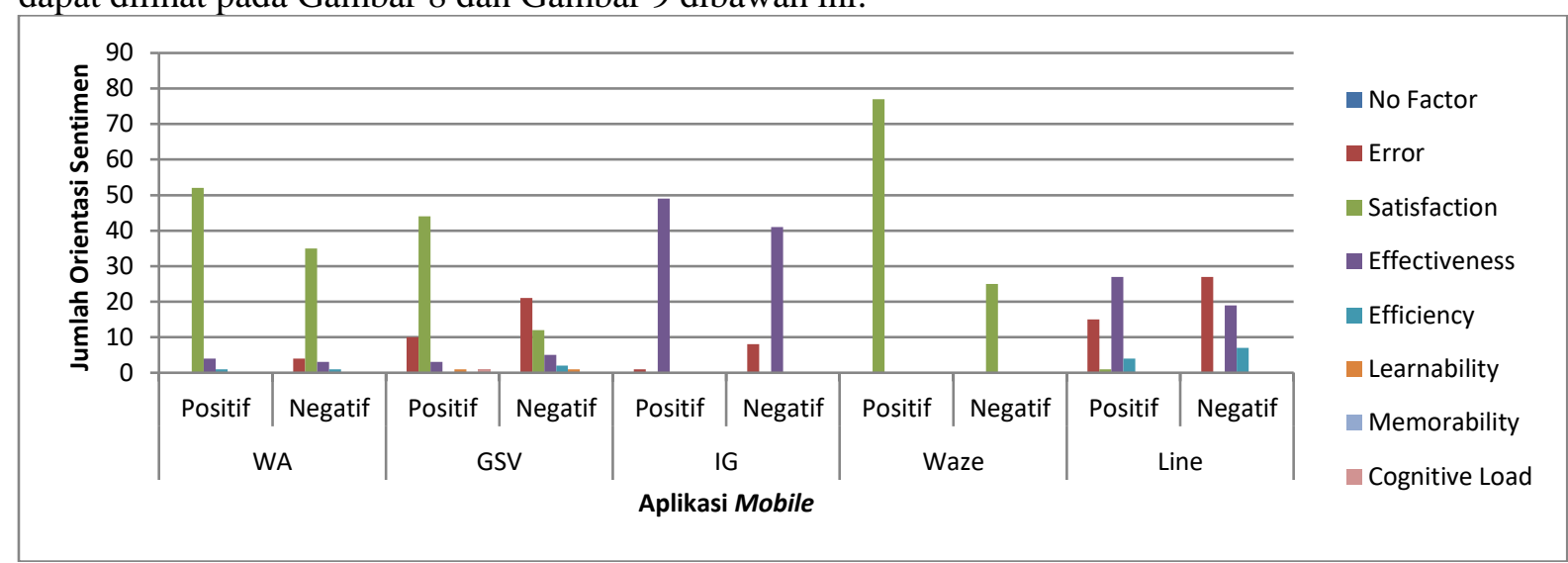

Gambar 8. Hasil evaluasi berdasarkan jumlah orientasi sentimen single-class

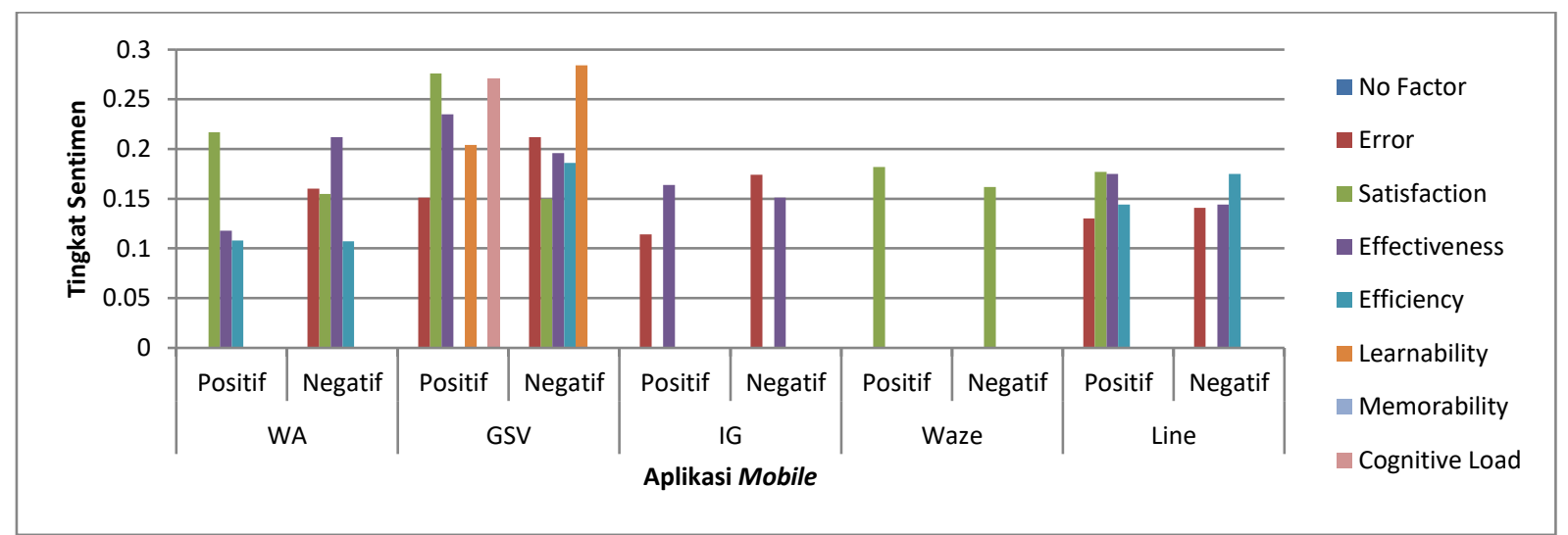

Gambar 9. Hasil evaluasi berdasarkan tingkat sentimen single-class

Berdasarkan hasil ujicoba pada Gambar 8 dan 9 maka dapat disimpulkan bahwa pada aplikasi Whatsapp Messenger, faktor satisfaction positif sangat dominan pada evaluasi aplikasi ini. Mengingat aplikasi Whatsapp Messenger merupakan aplikasi chatting yang stabil dan disukai banyak pengguna. Namun dalam faktor satisfaction juga terdapat sentimen negatif. Faktor satifaction negatif ini sebenarnya termasuk ke dalam false positive dalam metode single class. Selain itu ada dalam evaluasi ini diperoleh juga faktor error, namun bernilai kecil. Faktor error yang kecil pada aplikasi ini dikarenakan fitur baru voice to text yang belum bisa digunakan di beberapa merek smartphone serta fitur font style yang belum mendukung di beberapa bahasa.

Sama halnya dengan aplikasi Whatsapp Messenger, pada aplikasi Google Street View juga terdapat beberapa faktor usa yang dihasilkan dari evaluasi single-class yang meliputi satisfaction, error, effectiveness, learnability dan cognitive load. Pada aplikasi ini faktor satisfaction positif memang lebih dominan namun faktor error yang dihasilkan juga cukup tinggi. Berdasarkan hasil analisa, faktor error yang cukup tinggi dikarenakan beberapa fitur utama seperti search map, fitur 360 camera tidak bisa dijalankan di kebanyakan smartphone. 
Sedangkan pada aplikasi Instagram terdapat 2 faktor yang diperoleh berdasarkan hasil evaluasi yaitu faktor effectiveness dan error. Walaupun faktor effectiveness positif yang dihasilkan cukup tinggi, namun faktor effectiveness negatif juga cukup tinggi. Hal tersebut dikarenakan pada update terbaru instagram menghadirkan fitur baru yang berbeda dengan tujuan aplikasi instagram sebelumnya. Fitur tersebut antara lain adalah story yang sangat mirip dengan aplikasi snapchat sehingga banyak ditentang oleh para pengguna aplikasi ini dan fitur iklan dan akun bisnis yang mirip dengan facebook. Faktor error pada aplikasi lebih disebabkan karena aplikasi instagram masih memiliki bug yakni sering mengalami crash dan lost connection saat digunakan.

Evaluasi pada aplikasi Waze menghasilkan faktor satisfaction yang sangat tinggi. Hal tersebut dikarenakan aplikasi ini sudah sangat stabil dan memiliki fitur yang dapat menampilkan kondisi lalu lintas secara real-time.

Sedangkan untuk aplikasi Line, ada 4 faktor yang diperoleh pada evaluasi usability yaitu error, satisfaction, effectiveness dan effeciency. Hal tersebut dikarenakan aplikasi Line merupakan aplikasi sosial media dengan fitur terbanyak jika dibandingkan dengan aplikasi lain. Berdasarkan hasil analisa, faktor-faktor usability pada aplikasi Line lebih mengarah ke negatif, kecuali faktor effectiveness yang cukup tinggi. Faktor negatif tersebut lebih disebabkan oleh beberapa fitur Line yang belum berjalan maksimal. Sedangkan faktor error yang tinggi lebih dikarenakan banyaknya terjadi crash pada saat membuka Line today dan tidak dapat mengganti foto profil.

Hasil dari klasifikasi single class tersebut kemudian dibandingkan dengan hasil klasifikasi multi class yang diusulkan dalam penelitian ini. Untuk hasil ujicoba klasifikasi multi class dapat dilihat pada Gambar 10 dan Gambar 11 dibawah ini.

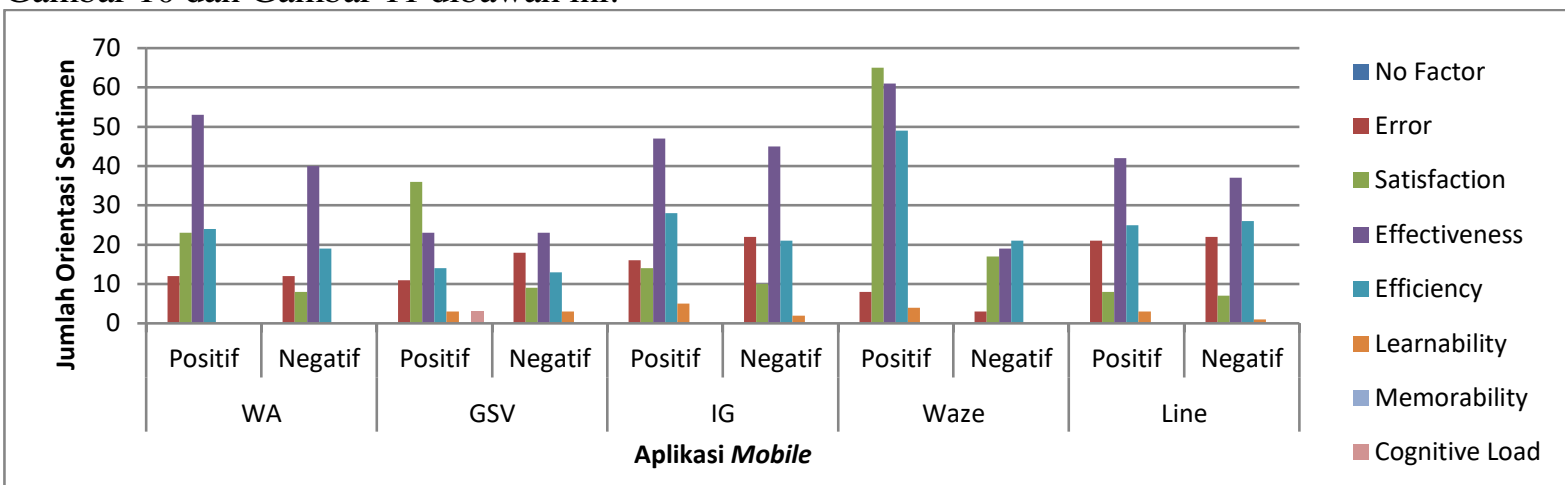

Gambar 10. Hasil evaluasi berdasarkan orientasi sentimen multi-class

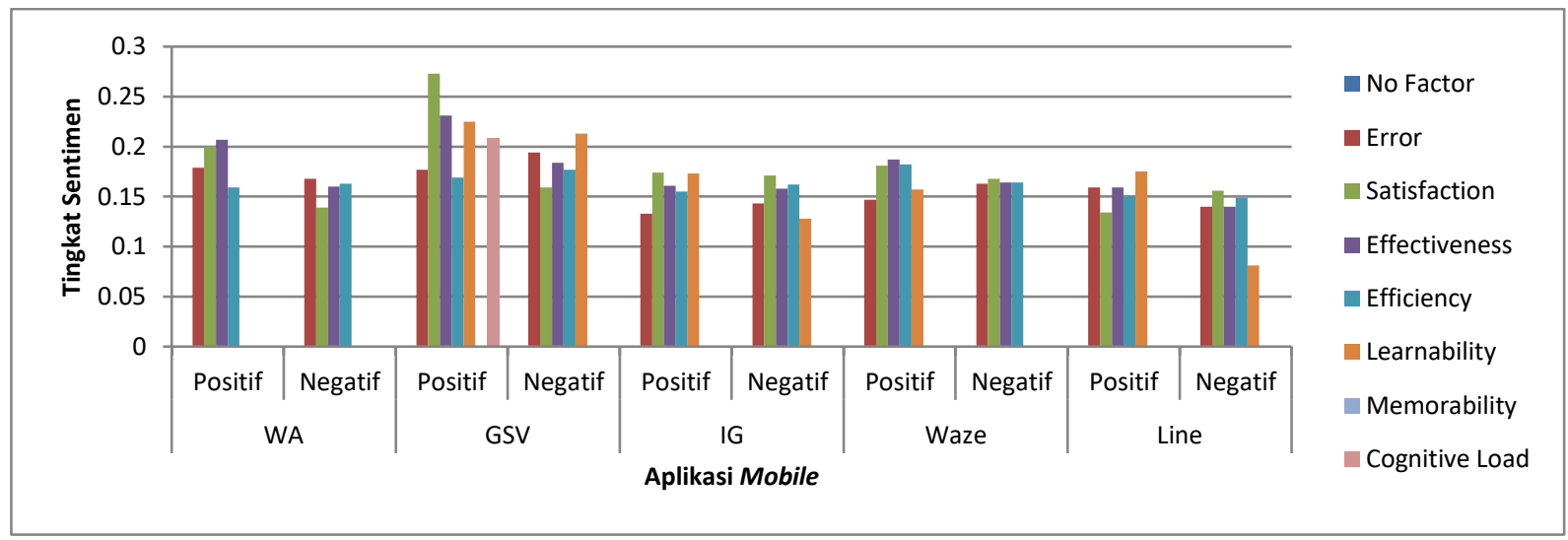

Gambar 11. Hasil evaluasi berdasarkan tingkat sentimen multi-class

Berdasarkan hasil evaluasi faktor usability dengan menggunakan multi class pada Gambar 10 dan Gambar 11 diatas maka diperoleh hasil faktor usability yang lebih variatif jika dibandingkan dengan hasil evaluasi faktor usability single class. Sebagai contoh pada aplikasi Waze pada analisa multi class menghasilkan 5 faktor usability yang antara lain adalah effectiveness, satisfaction, error, learnability 
dan efficiency. Namun pada analisa single class hanya diperoleh 1 faktor usability yaitu satisfaction. Begitu juga hasil evaluasi pada aplikasi lainnya yang juga menghasilkan faktor usability yang lebih banyak. Terbukti bahwa dengan menggunakan klasifikasi multi class, hasil evaluasi faktor usability yang diperoleh lebih detail dan lengkap. Hal tersebut dikarenakan metode klasifikasi multi class lebih mempertimbangkan faktor usability dari tingkat kalimat sampai ke tingkat opini, sehingga faktor usability yang terkandung dalam suatu opini dapat dikeluarkan secara menyeluruh dan tidak diwakilkan pada satu faktor usability yang paling dominan.

\subsection{Analisa Akurasi}

Proses analisa akurasi yang dilakukan dalam penelitian meliputi analisa perhitungan precision, recall, f-measure dan akurasi itu sendiri. Dalam proses analisa akurasi akan dilakukan 2 proses analisa akurasi yaitu analisa akurasi faktor usability dan analisa akurasi sentimen. Analisa akurasi faktor usability adalah mengukur nilai akurasi klasifikasi faktor usability berdasarkan metode yang diusulkan dengan data sesungguhnya yang meliputi analisa akurasi faktor usability single class dan multi class. Sedangkan analisa akurasi sentimen adalah pengukuran nilai akurasi dari hasil klasifikasi orientasi sentimen dengan rating data opini pengguna.

\subsubsection{Analisa Akurasi Klasifikasi Faktor Usability}

Pada proses analisa evaluasi faktor usability single class ini dilakukan mencocokkan hasil evaluasi faktor usability dengan prioritas utama faktor usability dari opini yang sudah diberi label oleh para ahli.

Rata-rata precision pada analisa single class adalah $28.5 \%$, recall $28.4 \%$ dan $f$-measure $28.5 \%$. Nilai precision dan recall yang cukup rendah lebih dikarenakan oleh nilai precision dan recall dari faktor usability memorability yang bernilai 0, sehingga sangat mempengaruhi rata-rata perhitungan precision dan recall. Selain itu pada analisa single class ini, precision memiliki nilai yang hampir sama dengan recall dikarenakan apabila terjadi perbedaan antara hasil faktor usability dari metode single class dan hasil dari para ahli maka data uji tersebut termasuk ke dalam false positive maupun false negative. Sebagai contoh apabila sistem menghasilkan faktor error sedangkan ahli memberi label effectiveness maka opini tersebut bisa digolongkan ke dalam $f p$ maupun $f n$. Hasil dari precision, recall dan $f$-measure pada analisa single class dapat dilihat pada Tabel 3 dan Gambar 12 dibawah ini.

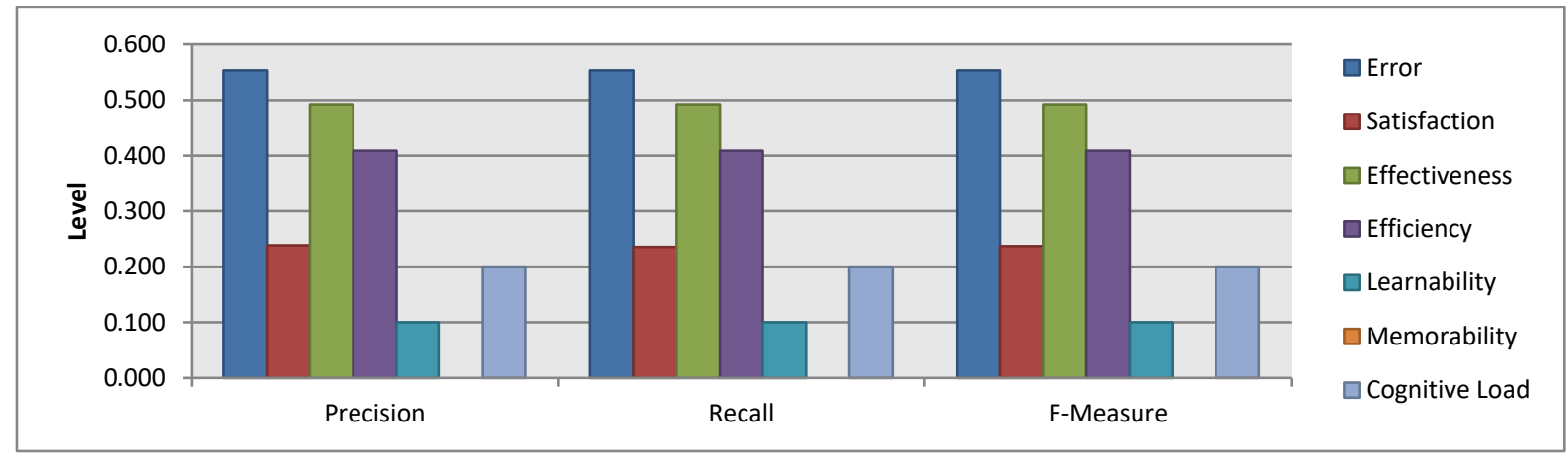

Gambar 12. Diagram hasil analisa single-class

Tabel 3. Hasil analisa precisión, recall dan f-measure single-class

\begin{tabular}{|l|r|r|r|}
\hline \multicolumn{1}{|c|}{ Faktor Usability } & Precision & \multicolumn{1}{c|}{ Recall } & F-Measure \\
\hline Error & 0.553 & 0.553 & 0.553 \\
\hline Satisfaction & 0.239 & 0.236 & 0.237 \\
\hline Effectiveness & 0.493 & 0.493 & 0.493 \\
\hline Efficiency & 0.409 & 0.409 & 0.409 \\
\hline Learnability & 0.100 & 0.100 & 0.100 \\
\hline Memorability & 0.000 & 0.000 & 0.000 \\
\hline
\end{tabular}




\begin{tabular}{|l|r|r|r|}
\hline Faktor Usability & Precision & \multicolumn{1}{c|}{ Recall } & F-Measure \\
\hline Cognitive Load & 0.200 & 0.200 & 0.200 \\
\hline Rata-rata & $\mathbf{0 . 2 8 5}$ & $\mathbf{0 . 2 8 4}$ & $\mathbf{0 . 2 8 5}$ \\
\hline
\end{tabular}

Hampir sama dengan analisa pada single class, pada proses analisa evaluasi faktor usability multi class ini juga dilakukan dengan mencocokkan hasil evaluasi faktor usability multi class sistem dengan faktor usability dari opini yang sudah diberi label oleh para ahli. Perbedaannya hanya pada jumlah faktor usability yang dicocokkan yaitu lebih dari 1 faktor.

Rata-rata precision pada analisa multi class adalah $43.2 \%$, recall $29.5 \%$ dan $f$-measure $34.5 \%$. Seperti halnya dengan analisa single class, nilai rata-rata precision dan recall yang cukup rendah dikarenakan oleh nilai precision dan recall dari faktor usability memorability yang bernilai 0 , sehingga sangat mempengaruhi rata-rata perhitungan precision dan recall. Dimana pada data yang diujikan memang tidak ada satupun yang mengandung faktor usability memorability, sehingga nilai precision maupun recall yang diperoleh faktor ini adalah 0 . Hasil dari precision, recall dan $f$-measure pada analisa multi class dapat dilihat pada Tabel 4 dan Gambar 13 dibawah ini.

\section{Tabel 4. Hasil analisa precisión, recall dan f-measure multi-class}

\begin{tabular}{|l|r|r|r|}
\hline Faktor Usability & \multicolumn{1}{c|}{ Precision } & \multicolumn{1}{c|}{ Recall } & \multicolumn{1}{c|}{ F-Measure } \\
\hline Error & 0.514 & 0.388 & 0.436 \\
\hline Satisfaction & 0.507 & 0.412 & 0.448 \\
\hline Effectiveness & 0.897 & 0.499 & 0.639 \\
\hline Efficiency & 0.603 & 0.425 & 0.493 \\
\hline Learnability & 0.369 & 0.260 & 0.302 \\
\hline Memorability & 0.000 & 0.000 & 0.000 \\
\hline Cognitive Load & 0.133 & 0.080 & 0.100 \\
\hline Rata-rata & $\mathbf{0 . 4 3 2}$ & $\mathbf{0 . 2 9 5}$ & $\mathbf{0 . 3 4 5}$ \\
\hline
\end{tabular}

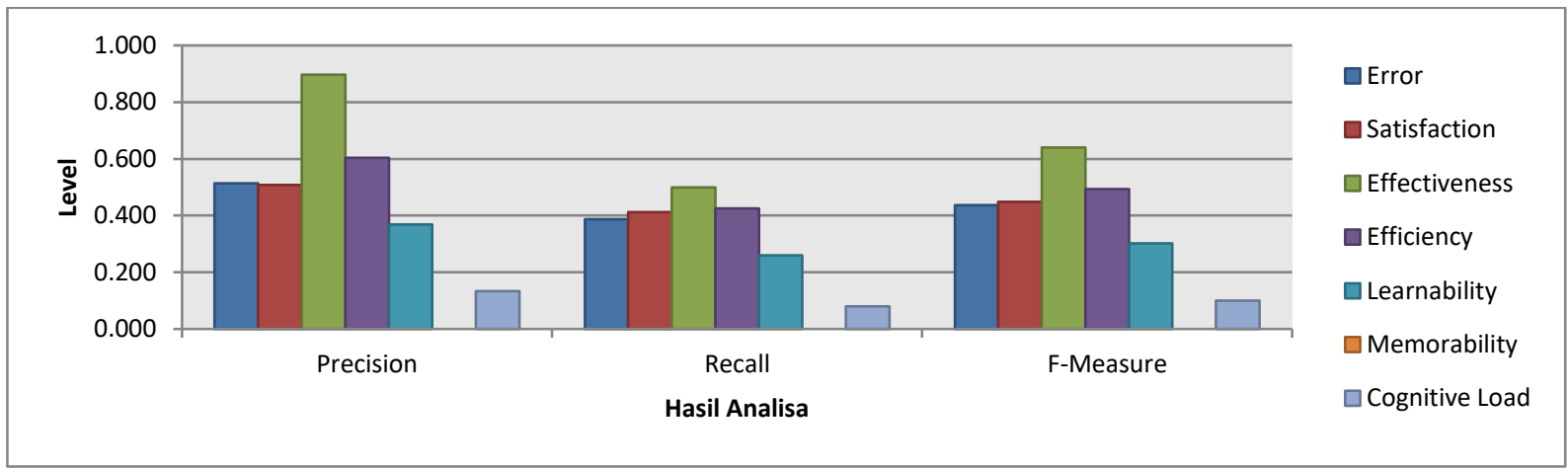

Gambar 13. Diagram hasil analisa multi-class

Nilai precision dan recall tertinggi dalam analisa multi class ini adalah nilai precision dan recall pada faktor effectiveness yaitu sebesar $89.7 \%$ dan $49.9 \%$. Perbedaan nilai precision dan recall dalam pengujian multi class ini disebabkan oleh perbedaan jumlah faktor yang dikeluarkan oleh sistem dengan para ahli. Apabila semakin banyak faktor usability relevan yang terambil oleh sistem maka nilai precision akan semakin tinggi.

Selain menghitung nilai precision, recall dan $f$-measure, pada penelitian ini juga dihitung nilai akurasi. Nilai akurasi diperoleh dari perbandingan jumlah data pengujian yang dianggap benar dengan keseluruhan data yang diujikan. Berdasarkan hasil analisa single class dan multi class maka diperoleh nilai akurasi single class sebesar $46 \%$ dan multi class sebesar $74.7 \%$. 
Berdasarkan hasil perbandingan nilai akurasi, precision, recall dan $f$-measure pada Tabel 5 maka dapat disimpulkan bahwa pada pengujian evaluasi faktor usability aplikasi mobile dalam penelitian ini, penggunaan klasifikasi faktor kebergunaan secara multi class dengan menggunakan metode Naive Bayes lebih baik daripada klasifikasi faktor usability single class. Hal tersebut dapat dilihat pada Gambar 14, dimana pada keseluruhan jenis pengukuran klasifikasi multi class lebih unggul daripada single class.

Untuk hasil perbandingan dan pengukuran precision, recall, f-measure dan akurasi pada analisa single class dan multi class penelitian ini dapat dilihat pada Tabel 5 dan Gambar 14 dibawah ini.

Tabel 5. Hasil perbandingan precision, recall, f-measure dan akurasi

\begin{tabular}{|l|r|r|r|r|}
\hline \multicolumn{1}{|c|}{ Jenis Analisa } & Precision & \multicolumn{1}{c|}{ Recall } & \multicolumn{1}{c|}{ F-Measure } & \multicolumn{1}{c|}{ Akurasi } \\
\hline Single Class & 0.285 & 0.284 & 0.285 & 0.460 \\
\hline Multi Class & 0.432 & 0.295 & 0.345 & 0.747 \\
\hline
\end{tabular}

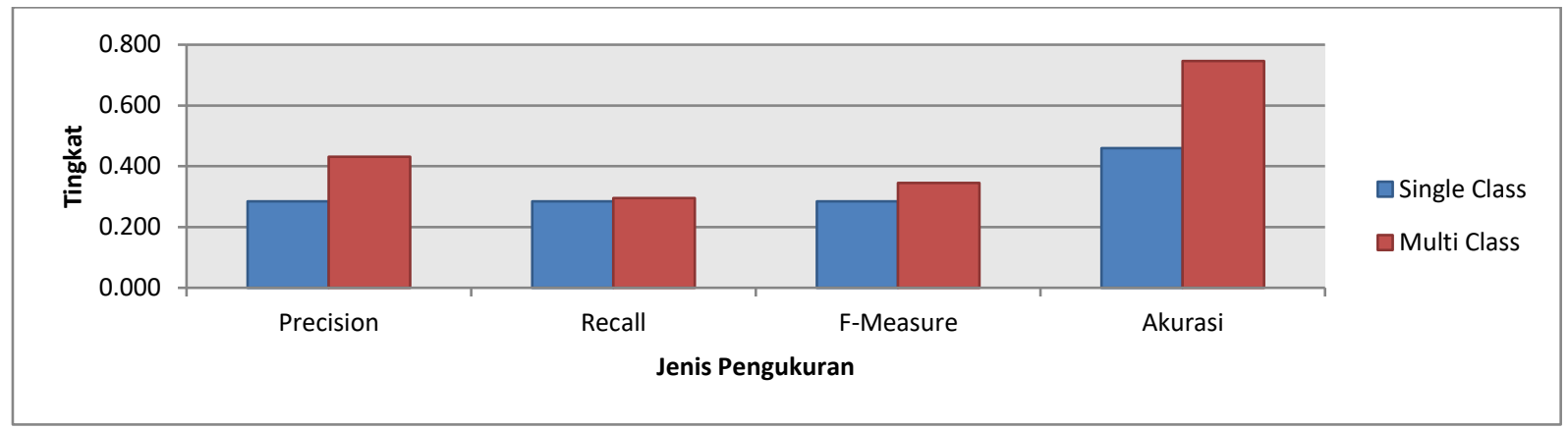

Gambar 14. Perbandingan hasil analisa single-class dan multi-class

Pendekatan multi class lebih baik apabila dibandingkan dengan single class dikarenakan pada dokumen opini pengguna yang terdiri dari beberapa kalimat sangat dimungkinkan memiliki lebih dari 1 faktor atau class. Dimana pengguna dapat mengekspresikan persepsi yang berbeda pada setiap kalimat yang ada pada suatu opini pengguna aplikasi mobile. Selain itu ada juga beberapa faktor yang mempengaruhi tinggi rendahnya nilai precision, recall dan akurasi. Beberapa faktor tersebut antara lain adalah sebagai berikut.

- Metode single class berdasarkan pembobotan kata terhadap class usability lebih bergantung pada frekuensi dan nilai $I C F$ pada setiap kata pada opini yang diujikan, sehingga sangat bergantung faktor kebergunaan yang paling dominan pada data latih. Sebagai contoh pada pengujian aplikasi Waze dikarenakan data latih yang didominasi oleh faktor satisfaction maka keseluruhan faktor yang dihasilkan sistem juga satisfaction.

- Persepsi ahli yang memprioritaskan faktor usability dari suatu kata atau kalimat tertentu dalam suatu opini, namun metode klasifikasi single class menganalisa opini secara keseluruhan sehingga menghasilkan faktor usability yang berbeda.

- Metode klasifikasi multi class yang diusulkan mempertimbangkan faktor usability dari tingkat kalimat sampai tingkat opini, sehingga hasil faktor usability yang dihasilkan kebanyakan sama dengan persepsi para ahli.

\subsubsection{Analisa Akurasi Sentimen}

Pada analisis sentimen ini orientasi sentimen pada data yang telah akan dicocokkan dengan rating yang ada pada opini pengguna yang bersangkutan. Berdasarkan hasil pengukuran precision, recall dan $f$-measure diperoleh nilai rata-rata precision, recall dan f-measure yang dihasilkan sebesar $43 \%$, $46.1 \%$ dan $44.1 \%$. Nilai rata-rata pengukuran yang diperoleh cukup rendah dikarenakan tidak adanya opini yang menghasilkan nilai sentimen netral ketika diujikan, sehingga nilai 0 pada sentimen netral 
sangat mempengaruhi nilai rata-rata pengukuran sentimen pada penelitian ini. Untuk lebih jelasnya dapat dilihat perbandingan jenis pengukuran terhadap orientasi sentimen pada Gambar 15 dibawah ini.

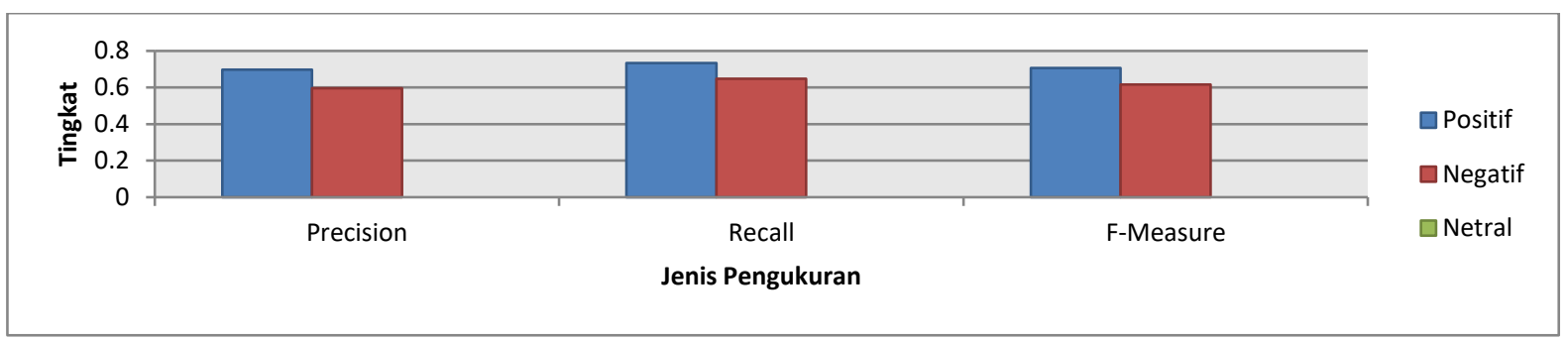

Gambar 15. Perbandingan jenis pengukuran analisa sentimen

Berdasarkan diagram pada Gambar 15 diatas maka dapat disimpulkan bahwa sebenarnya nilai precision, recall dan $f$-measure pada sentimen positif dan negatif cukup tinggi. Hanya sentimen netral saja yang tidak memiliki nilai dalam keseluruhan jenis pengukuran, sehingga sangat mempengaruhi keseluruhan nilai pengukuran. Selain precision, recall dan $f$-measure dalam penelitian ini juga dilakukan pengukuran akurasi. Berdasarkan hasil pengujian yang dilakukan pada analisis sentimen maka diperoleh nilai akurasi sebesar 67.8\%. Gambar 16 dibawah ini menunjukkan perbandingan nilai precision, recall dan $f$-measure pada analisis sentimen dalam penelitian ini.

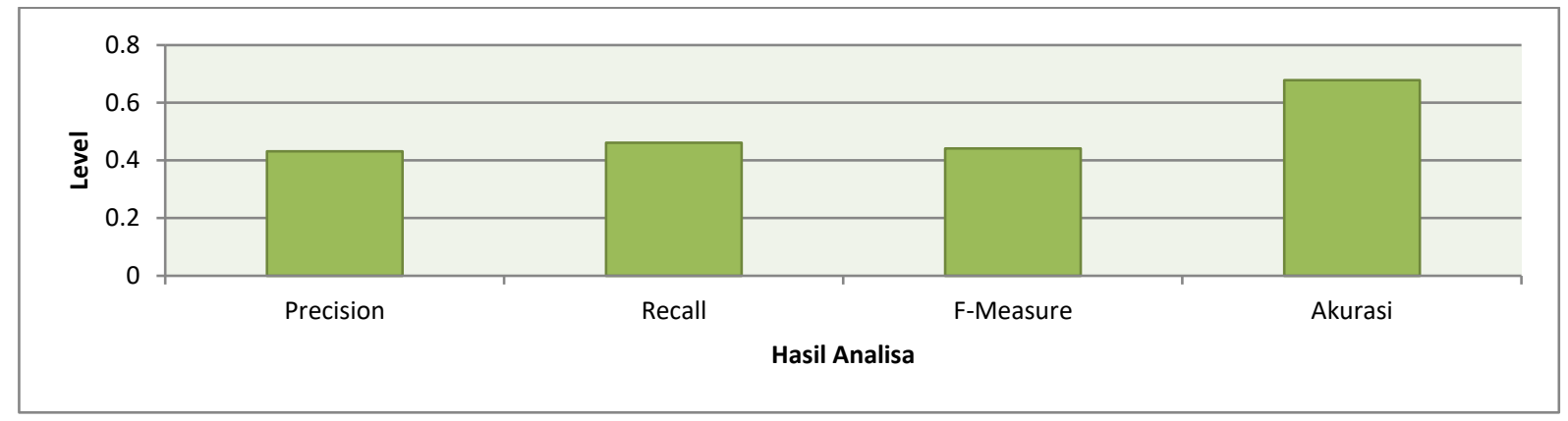

Gambar 16. Perbandingan jenis pengukuran analisa sentimen secara umum

Berdasarkan perbandingan hasil precision, recall, f-measure dan akurasi pada Gambar 16 terdapat beberapa faktor yang mempengaruhi tinggi rendahnya nilai akurasi sentimen. Beberapa faktor tersebut antara lain adalah sebagai berikut.

- Opini dari pengguna yang sebenarnya bersifat negatif namun pengguna memberi rating positif yaitu rating 4 dan 5 . Berikut merupakan contoh opini dalam kasus tersebut. "it takes about 15 secondes to connect while the call is picked up. can you guy loom into it" - Rating 4 -. Opini diatas sebenarnya mengandung sentimen negatif namun pengguna memberi rating tinggi.

- Analisis sentimen yang digunakan berbasis SentiInterpretation yang berarti memanfaatkan bobot positif dan negatif berdasarkan tagging pada kata sehingga belum mempertimbangkan faktor kontekstual dalam kalimat maupun dokumen. Berikut merupakan contoh opini dalam kasus tersebut. "Too many problems It's a shame, because it's a good app, But the store doesnt work, luckily $i$ did not buy points yet but that doesnt work either, $i$ should have 40 points but it says otherwise" - Rating 1 -. Jika dianalisa secara mendalam, review tersebut sebenarnya bersifat negatif. Namun karena kata "shame" memiliki nilai positif yang tinggi yaitu sebesar 0.625 , sehingga keseluruhan kalimat dalam review akan tertutup oleh nilai positif kata tersebut.

- Opini yang memiliki rating 3. Namun ketika di evaluasi nilai sentimen positif dan negatif dihasilkan tidak sama, sehingga orientasi yang dihasilkan menjadi bukan netral melainkan akan cenderung kearah positif atau negatif.

- Nilai tingkat sentimen opini yang hampir sama. Berikut merupakan contoh review dalam kasus tersebut. "Video Calling problems Can't hear the dial tone or the person on the end 
of the call when i make a video call but they can hear me" - Rating 1-. Opini diatas memiliki nilai sentimen positif sebesar 0.0354 dan nilai sentimen negatif sebesar 0.0311 , namun rating yang diberikan oleh pengguna adalah 1.

\section{Kesimpulan}

Evaluasi faktor usability aplikasi mobile berdasarkan opini pengguna dapat dilakukan dengan mengklasifikasikan opini berdasarkan faktor usability serta melakukan analisis sentimen untuk menentukan orientasi sentimen dari opini. Sehingga melalui hasil tersebut maka faktor usability dan orientasi sentimen opini diperoleh. Penelitian ini menggunakan faktor usability PACMAD dan analisis tingkat sentimen untuk mengevaluasi faktor usability aplikasi mobile.. Berdasarkan hasil pengujian dengan menggunakan precision, recall, $f$-measure dan akurasi, evaluasi faktor usability dengan menggunakan multi class terbukti lebih baik jika dibandingkan dengan single class yaitu dengan nilai akurasi sebesar $74,7 \%$, precision $43,2 \%$, recall $29,5 \%$ dan $f$-measure $34,5 \%$. Selain itu, faktor usability yang dihasilkan pada proses evaluasi lebih detail dan lengkap jika dibandingkan dengan single class.

Tingkat sentimen juga perlu dipertimbangkan untuk evaluasi faktor usability dikarenakan dengan tingkat sentimen dapat diketahui kekurangan dari suatu aplikasi mobile berdasarkan faktor usability tertentu yang tidak bisa dideteksi hanya dengan data jumlah orientasi sentimen. Berdasarkan ujicoba, faktor usability memorability tidak ditemukan dalam keseluruhan data uji, sehingga penggunaannya dalam evaluasi faktor usability aplikasi mobile masih perlu dikaji kembali. Selain itu, penggunaan opini dengan rating 3 sebagai opini netral juga masih perlu dikaji kembali dikarenakan berdasarkan hasil ujicoba, opini dengan rating 3 tidak ada yang memiliki orientasi sentimen netral.

Untuk penelitian selanjutnya dapat menggunakan metode yang memperhatikan konteks dari opini yang diujikan seperti metode WSD atau Word Sense Disambiguation. Sehingga nantinya sense kata dalam suatu kalimat ataupun opini dapat diketahui terlebih dahulu sebelum kata tersebut dicocokkan dalam basis data SentiWordNet. Selain itu, penggunaan bahasa lain selain Bahasa Inggris juga dapat dipertimbangkan dalam penelitian berikutnya.

\section{Referensi}

Atoum, I., \& Otoom, A. (2016). Mining Software Quality from Software Reviews : Research Trends and Open Issues. International Journal of Computer Trends and Technology (IJCTT), 31(2), 74 83. https://doi.org/10.14445/22312803/IJCTT-V31P114

Baharuddin, R., Singh, D., \& Razali, R. (2013). Usability dimensions for mobile applications-a review. Research Journal of Applied Sciences, Engineering and Technology, 5(6), 2225-2231. https://doi.org/10.3991/ijim.v3s1.854

Ben, W., \& Karaa, A. (2013). A NEW STEMMER TO I MPROVE I NFORMATION RETRIEVAL, 5(4), 143-154.

El-Halees, A. M. (2014). Software usability evaluation using opinion mining. Journal of Software, 9(2), 343-349. https://doi.org/10.4304/jsw.9.2.343-349

Flood, D., Harrison, R., Iacob, C., \& Duce, D. (2012). Evaluating mobile applications: A spreadsheet case study. International Journal of Mobile Human Computer Interaction, 4(4), 37-65. https://doi.org/10.4018/jmhci.2012100103

Frank, E., \& Bouckaert, R. R. (n.d.). Naive Bayes for Text Classification with Unbalanced Classes.

Hamouda, A., \& Rohaim, M. (2011). Reviews classification using sentiwordnet lexicon. World Congress on Computer Science and ..., 2(2), 120-123. Retrieved from http://www.infomesr.org/attachments/123.pdf

Harrison, R., Flood, D., \& Duce, D. (2013a). Usability of mobile applications : literature review and rationale for a new usability model, $1-16$.

Harrison, R., Flood, D., \& Duce, D. (2013b). USABILITY OF MOBILE APPLICATIONS Usability of Mobile Applications: Literature Review and Rationale for A New Usability Model Usability of Mobile Applications: Literature Review and Rationale for A New Usability Model, 1-16. https://doi.org/10.1186/2194-0827-1-1 
Kaur, A., \& Gumber, N. (2014). Sentimental Analysis on Application Reviews on Educational Apps, (11), 16-19.

Lapin, K. (2014). Deriving Usability Goals for Mobile Applications. Proceedings of the 2014 Mulitmedia, Interaction, Design and Innovation International Conference on Multimedia, Interaction, Design and Innovation - MIDI '14, 1-6. https://doi.org/10.1145/2643572.2643576

Lo, R. T., He, B., \& Ounis, I. (n.d.). Automatically Building a Stopword List for an Information Retrieval System.

Ohana, B., \& Tierney, B. (2009). Sentiment classification of reviews using SentiWordNet. School of Computing 9th. IT \& $T$ Conference, 13. Retrieved from http://arrow.dit.ie/cgi/viewcontent.cgi?article=1000\&amp;context=ittpapnin

Padioleau, Y. (2010). Pfff: Parsing PHP Programmer' s Manual and Implementation.

Patel, N. N., \& Dalal, P. (2013). Usability Evaluation of Mobile Applications. International Journal of Engineering Research \& Technology (IJERT), 2(11), 299-302. https://doi.org/10.1145/1134285.1134500

Sharma, N., \& Chitre, V. (2014). Opinion Mining, Analysis and its Challenges, 3(1), 59-65. Retrieved from http://www.academicscience.co.in/admin/resources/project/paper/f201403261395847402.pdf

Vidyapith, B. (2014). O Pinion Mining of Movie Reviews At, 3(3), 13-21.

Wardhana, S. R., Purwitasari, D., \& Rochimah, S. (n.d.). Analisis Sentimen Pada Review Pengguna Aplikasi Mobile Untuk Evaluasi Faktor Usability, 1-9.

Zaid, B., Jamaludin, R., \& Wafaa, B. (2012). A Comparative Study of Usability Methods for Mobile Applications. International Journal of Scientific \& Engineering Research, 3(8), 1-4. Retrieved from http://citeseerx.ist.psu.edu/viewdoc/download?doi=10.1.1.302.6747\&rep=rep1\&type=pdf

Zhikov, V., Tolo, L., Ivanov, Y., \& Georgiev, G. (n.d.). Multi- Class, Label and Language Document Classification: System and Features. 